\title{
Penerapan Hak Imunitas Dalam Melindungi Hak Konstitusional Anggota Dewan Perwakilan Rakyat Daerah (DPRD)
}

\author{
Lanang Sakti \\ Prodi S1 Hukum, Universitas Bumigora \\ email : lanangsakti1312@gmail.com
}

The right of immunity is given to members of the legislative with a view to guaranteeing the status of legislative members and preventing legislative members from misusing the authority of the authorities in the activities of the people's representatives. The code was maked of Law Number 27 of 2009 which was later revoked and replaced by Law Number 17 of 2014 concerning the People's Consultative Assembly, the House of Representatives, the Regional Representative Council, and the Regional People's Representative Council in lieu of Law Number 22 of 2003, has caused a change in relation to the immunity rights of members of the DPR. Amendements to the Article which regulates the immunity rights of DPR members are referred to as the extension of immunity rights because their limits have been extended.

\section{Keyword: immunity, legislative, amandement}

Hak imunitas diberikan kepada anggota legislatif dengan maksud untuk menjamin status anggota legeslatif dan mencegah anggota legeslatif untuk penyalahgunaan wewenang pihak penguasa dalam kegiatan para wakil rakyat. Lahirnya UU Nomor 27 Tahun 2009 yang kemudian dicabut dan digantikan dengan UU Nomor 17 Tahun 2014 Tentang Majelis Permusyawaratan Rakyat, Dewan Perwakilan Rakyat, Dewan Perwakilan Daerah, dan Dewan Perwakilan Rakyat Daerah sebagai pengganti Undang-Undang Nomor 22 Tahun 2003, telah menyebabkan perubahan kaitannya dengan hak imunitas anggota DPR. Perubahan Pasal yang mengatur tentang hak imunitas anggota DPR disebut sebagai perluasan hak imunitas karena batasannya telah diperluas.

\section{Kata Kunci : Hak Imunitas, legislative, amandemen}

\section{PENDAHULUAN}

Negara Kesatuan Republik Indonesia adalah negara demokrasi yang bersendikan kedaulatan rakyat dan bertumpu pada konstitusi atau Undang-Undang Dasar Tahun 1945. Kedaulatan Rakyat mempunyai makna yang sangat penting dalam melaksanakan kekuasaan negara sebagai dasar untuk merumuskan kebijakan terhadap berbagai urusan pemerintahan sehingga memiliki kekuatan sesuai dengan yang diamanatkan oleh rakyat. Dengan demikian, rakyat mempunyai hak untuk menentukan atau ikut mempengaruhi atas rumusan keputusan yang dikeluarkan oleh pemerintah. Untuk mengimplentasikan esensi dari kedaulatan rakyat itu dilaksanakan melalui lembaga perwakilan rakyat.

Lembaga perwakilan rakyat sebagai perwujudan dari sistem demokrasi yang akan melaksanakan terhadap isi kemauan atau kebutuhan dari rakyat. Karena itu, keberadaan lembaga perwakilan 
rakyat yang dibentuk untuk memproses penyelenggaraan pemerintahan yang dilaksanakan oleh institusi pemerintahan yang dalam hal ini ialah fungsi eksekutif. Dalam mencerminkan unsur rakyat yang akan diwakili, harus dilakukan melalui proses pemilihan umum. Melalui pemilihan umum rakyat dapat menggunakan hak politiknya dalam memilih para wakil-wakil rakyat sebagai perwujudan suatu sistem pemerintahan yang demokratis. Karena dengan azas demokrasi rakyat diberi kebebasan untuk ikut serta dalam proses pemerintahan. "Menurut Abraham Lincoln suatu Negara demokratis adalah Negara yang memiliki bentuk pemerintahan oleh rakyat dan untuk rakyat yang merupakan makna demokrasi dimana rakyat berhak mengawasi jalannya dan ikut serta dalam pemerintahan" ${ }^{[1]}$.

Esensi dari lembaga perwakilan rakyat (DPR/DPRD) merupakan elemen penyelenggara pemerintahan negara yang bersifat kemitraan dengan lembaga eksekutif (Pemerintah) untuk melaksanakan amanat peraturan perundang-undangan berdasarkan prinsip kedaulatan rakyat melalui produk lembaga legislatif. Lembaga legislatif (DPR/DPRD) dalam suatu negara hukum yang demokratis terinspirasi dari ajaran teori trias politika yang dikembangkan oleh Montesquieu yang di dalamya membagi kekuasaan negara menjadi tiga macam, yakni Kekuasaan Legislatif, Kekuassaan Eksekutif dan Kekuasaan Yudikatif.

Lembaga legislatif juga memiliki peran yang sangat penting dan strategis dalam kehidupan bernegara karena merupakan representasi dari rakyat. Di Indonesia lembaga perwakilan atau parlemen dibedakan ke dalam tiga fungsi, yaitu fungsi legislasi (legislatif), fungsi pengawasan (control) dan fungsi anggaran (budgeting) ${ }^{[2]}$.

Berdasarkan ketiga fungsi tersebut yang dijalankan secara kelembagaan, maka setiap anggota lembaga legislatif memiliki hak-hak tertentu yang telah dijamin secara yuridis konstitusional telah diatur keberadaannya dalam Pasal 20A ayat (3) Undang-Undang Dasar Negara Republik Indonesia Tahun 1945 yang menyatakan bahwa Selain hak yang diatur dalam pasal-pasal lain Undang-Undang Dasar ini, Dewan Perwakilan Rakyat mempunyai hak mengajukan pertanyaan, menyampaikan usul dan pendapat, serta hak imunitas.

Dari beberapa hak yang dimilki oleh anggota legislatif, hak imunitas menjadi perdebatan dikarenakan seorang anggota legislatif diberikan hak kekebalan atau imunitas. Hak imunitas anggota legislatif adalah hak anggota DPR untuk tidak dapat dituntut didepan pengadilan karena pernyataan, pertanyaan, dan atau pendapat yang dikemukakan secara lisan maupun tertulis di dalam rapat maupun di luar rapat DPR. Pengaturan yang lebih khusus tentang hak imunitas tercantum dalam Undang-Undang Nomor 17 Tahun 2014 tentang MPR, DPR, DPD dan DPRD.

Hak imunitas diberikan kepada anggota legislatif dengan maksud untuk menjamin status anggota legeslatif dan mencegah anggota legeslatif untuk penyalahgunaan wewenang pihak penguasa dalam kegiatan para wakil rakyat. Namun secara sosiologis, makna dari hak imunitas anggota legislatif mempunyai nuansa yang masih dipahami secara kabur oleh elemen masyarakat sehingga memberikan pengertian yang bermakna negatif dari segi fungsi hukum. Bahkan dapat dikatakan oleh sebagian kalangan masyarakat yang menempatkan hak imunitas itu sebagai sesuatu hak yang mengistimewakan para anggota legeslatif yang tidak dapat dituntut secara hukum.

Secara aktual dan kasuistis dapat dijadikan sebagai bukti yang telah menimpa beberapa anggota

\footnotetext{
Leo Agustino, Politik Hukum dan Otonomi Daerah, Banten, Untirta Press, 2005, hal.15

2 Jimly Asshiddiqie, Pokok-Pokok Hukum Tata Negara Indonesia, PT. Bhuana Ilmu Populer, Jakarta, 2007, hal. 160.
} 
legislatif seperti kasus tentang beberapa anggota legislatif yang akan di bawa ke jalur hukum karena tindak pidana pencemaran nama baik sampai terlibat dalam kasus Bank Century, cek pelawat Bank Indonesia, dan kasus suap Wisma atlet.

Berdasarkan fenomena kasus yang melibatkan beberapa anggota legislatif sebagaimana diuraikan di atas dapat memberikan suatu gambaran bahwa fatwa kalangan anggota legislatif dihadapkan dengan berbagai peristiwa yang menempatkan suatu tindakan atau bentuk perbuatannya bertentangan dengan ketentuan undang-undang yang berlaku. Sehingga harus dilakukan proses penegakkan hukum sesuai dengan peraturan perundang-undangan yang berlaku. Akan tetapi, pada sisi lain hak imunitas bagi setiap anggota legislatif diposisikan dengan keadaan yang dilindungi oleh keberadaan hak imunitas tersebut.

Dengan demikian keberadaan hak imunitas secara umum memberikan pengertian yang terkesan terkait dengan sifat kekebalan hukum yang dimiliki oleh kalangan anggota legislatif. Namun dalam negara hukum setiap warga negara mempunyai hak dan kewajiban yang sama terhadap ketentuan hukum yang berlaku. Oleh karena itu dalam kaitannya dengan hak imunitas bagi anggota legislatif baik itu di dalam DPR RI maupun di DPRD Provinsi dan Kabupaten/kota perlu dikaji dan dianalisis.

Penelitian ini merupakan penelitian hukum normatif yaitu penelitian hukum yang meletakkan hukum sebagai sebuah bangunan sistem norma, dengan menggunakan pendekatan perundangundangan (statute approach) dan pendekatan konseptual (conceptual approach). Teknik pengolahan dan pengumpulan bahan hukum yang di gunakan dalam penelitian ini adalah melalui studi kepustakaan (liberary reseach), dikumpulkan dengan teknik dokumentas yang meliputi studi bahanbahan hukum yang terdiri dari bahan hukum perimer, bahan hukum skunder, dan bahan hukum tersier yang ada kaitanya dengan masalah yang diteliti. Alat pengumpulan bahan hukum yang digunakan yaitu studi dokumen.

\section{PEMBASHASAN}

\section{A. Pengaturan Hak Imunitas Anggota Dewan Perwakilan Rakyat Daerah (DPRD)}

Istilah imunitas dalam bahasa bahasa Inggris berarti "immunity" yang artinya kekebalan, kata lainnya adalah "immunis" yang menyatakan "tidak dapat diganggu gugat". Imunitas dalam bahasa Belanda disebut "immuniteit" ${ }^{[3]}$ yang berarti kekebalan atau tidak tunduk kepada hukum yang berlaku disuatu Negara.

Pada prinsipnya hak imunitas yang dalam bahasa Indonesia disebut juga dengan hak kekebalan hukum, secara konstitusional telah diatur keberadaannya dalam Pasal 20A ayat (3) UndangUndang Dasar Negara Republik Indonesia Tahun 1945 yang berbunyi "selain hak yang diatur dalam pasal-pasal lain Undang-Undang Dasar ini, Dewan Perwakilan Rakyat mempunyai hak mengajukan pertanyaan, menyampaikan usul dan pendapat, serta hak imunitas".

Untuk menindaklanjuti amanat Undang-Undang Dasar tersebut, maka dibentuklah UndangUndang Nomor 22 Tahun 2003 tentang Susunan Dan Kedudukan Majelis Permusyawaratan Rakyat, Dewan Perwakilan Rakyat, Dewan Perwakilan Daerah, Dan Dewan Perwakilan Rakyat Daerah. Di dalam Pasal 28 Undang-undang Nomor 23 Tahun 2003 tentang Susunan Dan Kedudukan Majelis Permusyawaratan Rakyat, Dewan Perwakilan Rakyat, Dewan Perwakilan Daerah, dan Dewan

3 Subekti dan R. Tjitrosoedibio, Op. Cit. halaman 61 
Perwakilan Rakyat Daerah menyebutkan bahwa Anggota DPR mempunyai hak:

a. mengajukan rancangan undang-undang;

b. mengajukan pertanyaan;

c. menyampaikan usul dan pendapat;

d. memilih dan dipilih;

e. membela diri;

f. imunitas;

g. protokoler; dan

h. keuangan dan administratif.

Dalam penjelasan Undang-Undang Nomor 22 Tahun 2003 tentang Susunan Dan Kedudukan Majelis Permusyawaratan Rakyat, Dewan Perwakilan Rakyat, Dewan Perwakilan Daerah, Dan Dewan Perwakilan Rakyat Daerah, Pasal 28 huruf f disebutkan bahwa hak imunitas atau hak kekebalan hukum anggota DPR adalah hak untuk tidak dapat dituntut di muka pengadilan karena pernyataan dan pendapat yang disampaikan dalam rapat-rapat DPR dengan pemerintah dan rapatrapat DPR lainnya sesuai dengan peraturan perundang-undangan.

Lahirnya Undang-Undang Nomor 27 Tahun 2009 tentang Majelis Permusyawaratan Rakyat, Dewan Perwakilan Rakyat, Dewan Perwakilan Daerah, dan Dewan Perwakilan Rakyat Daerah sebagai pengganti Undang-Undang Nomor 22 Tahun 2003, telah menyebabkan perubahan kaitannya dengan hak imunitas anggota DPR. Perubahan Pasal yang mengatur tentang hak imunitas anggota DPR disebut sebagai perluasan hak imunitas karena batasannya telah diperluas.

Dalam Pasal 196 Undang-Undang Nomor 27 Tahun 2009 tentang MPR, DPR, DPD, dan DPRD menyebutkan bahwa :

(1) Anggota DPR mempunyai hak imunitas.

(2) Anggota DPR tidak dapat dituntut di depan pengadilan karena pernyataan, pertanyaan, dan/atau pendapat yang dikemukakannya baik secara lisan maupun tertulis di dalam rapat DPR ataupun di luar rapat DPR yang berkaitan dengan fungsi serta tugas dan wewenang DPR.

(3) Anggota DPR tidak dapat diganti antarwaktu karena pernyataan, pertanyaan, dan/atau pendapat yang dikemukakannya baik di dalam rapat DPR maupun di luar rapat DPR yang berkaitan dengan fungsi serta tugas dan wewenang DPR.

(4) Ketentuan sebagaimana dimaksud pada ayat (1) tidak berlaku dalam hal anggota yang bersangkutan mengumumkan materi yang telah disepakati dalam rapat tertutup untuk dirahasiakan atau hal lain yang dimaksud dalam ketentuan mengenai rahasia negara sesuai dengan ketentuan peraturan perundang-undangan.

Undang-Undang Nomor 27 Tahun 2009 tersebut di atas kemudian dicabut dan diganti oleh Undang-Undang Nomor 17 Tahun 2014 tentang MPR, DPR, DPD, dan DPRD, dimana ketentuan mengenai hak imunitas tidak jauh berbeda dengan ketentuan yang diatur dalam Undang-Undang sebelumnya yakni Undang-Undang Nomor 27 Tahun 2009.

Dalam Pasal 224 Undang-Undang Nomor 17 Tahun 2014, ditentukan bahwa :

(1) Anggota DPR tidak dapat dituntut di depan pengadilan karena pernyataan, pertanyaan, dan/atau pendapat yang dikemukakannya baik secara lisan maupun tertulis di dalam rapat DPR ataupun di luar rapat DPR yang berkaitan dengan fungsi serta wewenang dan tugas DPR. 
(2) Anggota DPR tidak dapat dituntut di depan pengadilan karena sikap, tindakan, kegiatan di dalam rapat DPR ataupun di luar rapat DPR yang semata-mata karena hak dan kewenangan konstitusional DPR dan/atau anggota DPR.

(3) Anggota DPR tidak dapat diganti antarwaktu karena pernyataan, pertanyaan, dan/atau pendapat yang dikemukakannya baik di dalam rapat DPR maupun di luar rapat DPR yang berkaitan dengan fungsi serta wewenang dan tugas DPR.

(4) Ketentuan sebagaimana dimaksud pada ayat (1) tidak berlaku dalam hal anggota yang bersangkutan mengumumkan materi yang telah disepakati dalam rapat tertutup untuk dirahasiakan atau hal lain yang dinyatakan sebagai rahasia negara menurut ketentuan peraturan perundang-undangan.

\section{B. Bentuk dan Wujud Hak Imunitas}

Undang-Undang Nomor 27 Tahun 2009 Tentang MPR, DPR, DPD dan DPRD, memberikan definisi bahwa hak imunitas adalah hak kekebalan hukum yang diberikan kepada Pejabat Negara, dalam hal ini anggota legislatif, dengan bentuk pemberian perlindungan hukum atas pernyataan, pertanyaan ataupun pendapat yang disampaikan anggota legislatif baik secara lisan maupun tulisan, di dalam ruang rapat dan/atau di luar ruang rapat, sepanjang berkaitan dengan fungsi serta tugas dan wewenang DPR. Perlindungan tersebut diwujudkan dengan tidak dapat dituntutnya anggota legislatif ke pengadilan, baik karena pencemaran nama baik ataupun perbuatan tidak menyenangkan, akibat dari pernyataan, pertanyaan ataupun pendapat yang disampaikan oleh anggota legislatif dalam forum rapat maupun diluar rapat kaitannya dengan fungsi serta tugas dan wewenang DPR.

Dengan demikian, dengan adanya hak imunitas seorang anggota DPR diharapkan dapat mengaktualisasikan keberadaannya sebagai wakil rakyat untuk melakukan fungsi legislasi, fungsi anggaran dan fungsi pengawasan. Namun tentunya dengan batasan dalam ruang lingkup fungsi, tugas dan wewenang DPR. Bagaimana jadinya apabila dalam pengemukaan pernyataan, pertanyaan dan pendapat dalam menjalankan fungsi DPR, seorang anggota DPR dilanda perasaan takut karena nantinya akan dituntut di jalur hukum, justru akan kontra produktif peran anggota parlemen kita sebagai wakil rakyat di mata masyarakat.

Pemberian perlindungan hukum tersebut seharusnya dapat dipergunakan sebaik-baiknya, secara profesional dan proporsional. Namun, terkadang beberapa oknum anggota legislatif tidak mampu menggunakan hak tersebut secara profesional dan proporsional, sehingga dalam menyampaikan pertanyaan, pernyataan ataupun pendapat didalam rapat maupun diluar rapat, baik itu tertulis maupun lisan, kurang mengindahkan tata tertib dan kode etik, sehingga oleh sebagian orang dianggap melecehkan.

Padahal patut diketahui, sesuai Pasal 1 angka 5 KUHAP, seseorang hanya dapat dinyatakan bersalah jika sudah ada penyelidikan untuk menentukan ada atau tidaknya pelanggaran, penyidikan untuk mencari pelaku, kemudian penuntutan, pendakwaan dan vonis. Semestinya sebagai wakil rakyat, DPR meskipun telah dibentengi dengan hakimunitas, tidak boleh secara semena-mena dalam menyampaikan pendapat, terutama dalam menvonis seseorang bersalah meski itu disampaikan dalam rapat resmi adalah perintah undang-undang. Bahwa anggota DPR diberi hak imunitas untuk melindungi diri saat menjalankan tugas harus dimanfaatkan dengan tidak menginjak-injak hukum juga adalah kewajiban. Seharusnya, hak itu digunakan dengan melihat rambu hukum yang memandang semua orang dengan kaca mata presumption of innocence. 
Berkaca pada pasal 310 KUHP yang mendalilkan "barang siapa dengan sengaja menyerang kehormatan atau nama baik seseorang dengan menuduhkan sesuatu hal, yang maksudnya terang supaya hal itu diketahui umum" diklasifikasikan sebagai pencemaran atau jika itu dimaksudkan untuk menghina, mengingat yang dihina itu umumnya adalah pegawai negeri ${ }^{[4]}$, diklasifikasikan sebagai penghinaan ringan oleh Pasal 315 jo Pasal 316 KUHP. Mengacu kepada aturan pidana di atas, ungkapan tersebut dapat dipandang sebagai pencemaran atau penghinaan, lebih-lebih jika dikaitkan dengan penjelasan Pasal 103 ayat (1) tersebut.

Berbicara mengenai pencemaran nama baik, dalam kajian ilmu hukum pidana adalalah termasuk dalam delik aduan (Klacht delicten), sehingga delik tersebut hanya dapat ditindak apabila telah ada pengaduan dari orang yang nama baiknya dicemarkan. Menurut P.A.F. Lamintang ${ }^{[5]}$ yang dimaksud dengan delik aduan tersebut adalah, delik-delik yang hanya dapat dituntut apabila ada suatu pengaduan dari orang yang merasa dirugikan itu didalam bahasa Belanda disebut "delicten allen op klachte vervolgbaar" atau didalam bahasa Jerman juga disebut Antragdelikte, yakni sebagai lawan dari apa yang disebut "delicten van ambtswege vervolgbaar" atau delik-delik yang dapat dituntut sesuai dengan jabatan.

Didalam Klacht delicten terdapat perbedaan mengenai absolute klachtdelict dan juga relatieve klachtdelict. Pada absolute klachtdelict, adanya sebuah pengaduan merupakan "voorwaarde van vervolgbaarheid" atau syarat agar pelakunya dapat dituntut. Dalam hal ini kata "pada dasarnya" sangat penting untuk ditekankan, karena tidak selalu keadaannya demikian, seperti dalam pasal 319 KUHP adalah delik aduan absolut tetapi apabila berkaca pada pasal 316 KUHP delik penghinaan tersebut bukanlah termasuk dalam delikaduan. "RelativeKlachtdelict", menurut Pompe ${ }^{[6]}$ adalah delik dimana adanya suatu pengaduan itu hanyalah merupakan suatu "voorwaarde voor vervolgbaarheid" atau suatu syarat untuk dapat menuntut pelakunya, dimana orang yang bersalah dengan orang yang dirugikan tersebut memiliki hubungan yang bersifat khusus.

\section{Batasan Hak Imunitas}

Perlindungan hukum kepada anggota legislatif dalam menjalankan fungsi serta tugas dan wewenangnya pada hak imunitas yang melekat padanya tidak semata-mata mutlak kebal hukum. Dalam hak imunitas itu sendiri secara tegas juga menyebutkan batasan-batasan hak imunitas. Seperti dalam Undang-Undang Nomor 22 Tahun 2003 tentang Susunan dan Kedudukan MPR, DPR, DPD dan DPRD, memberikan batasan bahwa hak imunitas tidak dapat digunakan di luar rapat DPR dengan Pemerintah atau rapat-rapat DPR lainnya. Itu artinya, hak imunitas itu hanya berlaku didalam rapat. Dalam Undang-undang tersebut juga memberikan penegasan dalam klausul pasal yang berbeda (Pasal 103 ayat 1) yaitu sepanjang tidak bertentangan dengan Peraturan Tata Tertib dan Kode Etik masing-masing lembaga.

Demikian pula halnya dalam Undang-Undang Nomor 27 Tahun 2009 sebagai pengganti Undang-Undang Nomor 22 Tahun 2003. Hak imunitas itu juga yang memberikan batasannya sendiri, seperti yang tercantum dalam Pasal 196 ayat 2 yaitu di dalam rapat DPR ataupun di luar rapat DPR yang berkaitan dengan fungsi serta tugas dan wewenang DPR. Yang menjadi perhatian penulis adalah tidak adanya klausul yang menyatakan "sepanjang tidak bertentangan dengan Peraturan

\footnotetext{
4 Sebagai contoh lihat kasus Jaksa Cirus Sinaga,yang divonis melakukan korupsi dalam kasus pengkaburan dakwaan Gayus Tambunan.

5 P.A.F. Lamintang, Dasar-dasar Hukum Pidana Indonesia, (Bandung;1997). hlm.218

6 Pompe,"Handboek van het Nederlanse Strafrecht",(Zwolle;1959), hlm.534
} 
Tata Tertib dan Kode Etik" seperti halnya Undang-Undang Nomor 22 Tahun 2003. Namun, yang menjadi pembatasan hak imunitas adalah kewajiban anggota legislatif itu sendiri, yang tertuang baik dalam Undang-Undang maupun Peraturan Tata Tertib dan Kode Etik. Dalam Pasal 79 huruf g Undang-Undang Nomor 27 Tahun 2009 disebutkan bahwa kewajiban anggota DPR adalah menaati tata tertib dan kode etik.

Batasan-batasan hak imunitas menurut Undang-Undang Nomor 27 Tahun 2009 antara lain :

a. Mematuhi Peraturan tata tertib dan kode etik;

b. Menyangkut Pertanyaan, pernyataan, dan/atau pendapat yang disampaikan oleh anggota legislatif, baik lisan maupun tulisan yang disampaikan dalam ruang rapat dan/atau diluar rapat;

c. Sepanjang berkaitan dengan fungsi serta tugas dan wewenang DPR.

Apabila batasan-batasan tersebut dilanggar, maka hak imunitas anggota legislatif dapat dicabut, dan dilakukan penuntutan ke pengadilan.

\section{KESIMPULAN}

Berdasarkan hasil penelitian yang penulis paparkan pada bab sebelumnya, maka dapat disimpulkan sebagai berikut :

1. Pengaturan hak imunitas bagi anggota legislatif berdasarkan peraturan perundang-undangan yang berlaku yang telah mengalami perubahan setelah Undang-Undang tentang Susunan dan Kedudukan MPR, DPR, DPD dan DPRD melalui Undang-Undang Nomor 22 Tahun 2003 dan peraturan perundang-undangan dibawahnya yaitu hak imunitas sebelumnya terbatas pada saat melaksanakan kegiatan rapat resmi yang telah diagendakan secara kelembagaan, sedangkan pada saat sekarang sesuai dengan hasil perubahan Undang-Undang tersebut menjadi UndangUndang Nomor 27 Tahun 2009 yang kemudian digantikan lagi oleh Undang-Undang Nomor 17 Tahun 2014, melekat pada keadaan di luar rapat resmi selama terkait dengan tugas, fungsi dan wewenang anggota legislatif.

2. Bentuk hak imunitas yang diberikan kepada anggota legislatif merupakan sebuah perlindungan hukum yang diwujudkan dengan tidak dapat dituntutnya anggota legislatif di depan pengadilan karena pernyataan, pertanyaan, dan/atau pendapat yang dikemukakannya baik secara lisan maupun tertulis di dalam rapat DPR ataupun di luar rapat DPR yang berkaitan dengan fungsi serta tugas dan wewenang DPR. Perlindungan hukum yang diberikan tidak bersifat mutlak.

\section{DAFTAR PUSTAKA}

Leo Agustino, Politik Hukum dan Otonomi Daerah, Banten, Untirta Press, 2005.

Jimly Asshiddiqie, Pokok-Pokok Hukum Tata Negara Indonesia, PT. Bhuana Ilmu Populer, Jakarta, 2007.

P.A.F. Lamintang, Dasar-dasar Hukum Pidana Indonesia, Bandung, 1997.

Pompe,"Handboek van het Nederlanse Strafrecht", Zwolle, 1959. 
Lanang Sakti | Penerapan Hak Imunitas Dalam Melindungi Hak Konstitusional Anggota. 